\title{
Evaluation of Childhood Traumas, Depressive Symptoms, and Dissociative Experiences in Tinnitus Cases
}

\section{Tinnitus Olgularında Çocukluk Çağı Travmaları, Depresif Belirtiler ve Dissosiyatif Yaşantıların Değerlendirilmesi}

\section{(1) Mustafa ALTINTASI, (1) Deniz SARLAK2, (1) Erdinc OZTURK³, (1) Osman CELBIS4}

'University of Health Sciences Turkey, Antalya Training and Research Hospital, Clinic of Otorhinolaryngology, Antalya, Turkey ${ }^{2}$ Mugla Sıtkı Kocman University Seydikemer School of Applied Sciences, Department of Social Services, Mugla, Turkey ${ }^{3}$ Istanbul University-Cerrahpasa, Institute of Forensic Sciences and Legal Medicine, Department of Social Sciences, Istanbul, Turkey ${ }^{4}$ Inonu University Faculty of Medicine, Department of Forensic Medicine, Malatya, Turkey

\begin{abstract}
Objective: Tinnitus is described as the perceived sound without any external stimulus and is a common problem, but its mechanism is not fully understood. This study aimed to evaluate childhood traumas and dissociative experiences, which may be predisposing factors in patients with tinnitus.

Methods: The study included 90 voluntary patients ( 45 patients with tinnitus and 45 in the control group) aged older than 18 years who applied to the otorhinolaryngology clinic between November 2018 and February 2019 and were diagnosed with subjective tinnitus. A personal information form together with childhood trauma, hospital anxiety and depression, and dissociative experiences scales were used to assess the patients.

Results: Of all participants, $55.60 \%$ were males, $28.90 \%$ were $20-30$ years old, $71.10 \%$ were married, $40 \%$ were primary school graduates, and $68.90 \%$ were employed. In addition, $77.78 \%$ of patients did not visit a psychiatrist and $75.56 \%$ did not have any chronic diseases. The mean total score of Childhood Trauma Scale for the tinnitus group was 54.37 \pm 10.17 , the mean total score of The Hospital Anxiety and Depression Scale for the tinnitus group in the depression subscale was $12.22 \pm 5.41$ and in the anxiety subscale was $10.54 \pm 3.5$, and Dissociative Experiences was $13.48 \pm 4.68$. A positive significant relationship was found between the childhood traumas of the tinnitus cases in their depressive symptoms, and dissociative experiences $(\mathrm{p}<0.05)$. Conclusions: The study results found a positive relationship between the childhood traumas and dissociative experiences of tinnitus cases, which can be considered as predisposing factors in patients with tinnitus who should also be investigated for childhood trauma, and the treatment approach should be multidisciplinary.
\end{abstract}

Keywords: Childhood traumas, dissociative experiences, depression, tinnitus

öz

Amaç: Tinnitus, herhangi bir dış uyaran olmaksızın alģılanan ses olarak tanımlanır ve yayğın bir sorundur, ancak mekanizması tam olarak anlaşılamamışıı. Bu çalışmada tinnituslu hastalarda predispozan faktör olabilecek çocukluk çağı travmaları ve dissosiyatif yaşantıların değerlendirilmesi amaçlanmıştır.

Yöntemler: Çalışmaya Kasım 2018-Şubat 2019 tarihleri arasında kulak burun boğaz polikliniğine başvuran ve subjektif tinnitus tanısı konulan 18 yaş üstü 90 gönüllü (tinnituslu 45 hasta ve kontrol grubunda 45 hasta) dahil edildi. Hastaları değerlendirmek için kişisel bilgi formu, çocukluk çağı travması, hastane anksiyetesi ve depresyonu ve dissosiyatif yaşantılar ölçekleri kullanıldı.
Received: 29.09.2021

Accepted: 16.11 .2021

Online First: 08 December 2021

Corresponding Author

M. Altintas

University of Health Sciences

Turkey, Antalya Training and

Research Hospital, Clinic of Otorhinolaryngology, Antalya, Turkey هr_altintas@yahoo.com

ORCID: 0000-0001-7436-2862 
Bulgular: Katılımcıların \%55,60'ı erkek, \%28,90'ı 20-30 yaş aralığında, \%71,10'u evli, \%40'ı ilkokul mezunu ve \%68,90'ı çalışmaktadır. Hastaların \%77,78'inin psikiyatriste gitmediği ve \%75,56'sının herhangi bir kronik hastalığı olmadığı belirlendi. Tinnituslu hastaların Çocukluk Çağı Travma Ölçeği toplam puanı $54,37 \pm 10,17$. Hastane Anksiyete ve Depresyon Ölçeği puanı 12,22 $\pm 5,41$, hastane anksiyete puanı $10,54 \pm 3,5$ ve Dissosiyatif Yaşantılar puanı $13,48 \pm 4,68$ olduğu tespit edildi. Tinnitus olgularının çocukluk çağı travmaları, depresif belirtileri ve dissosiyatif yaşantıları arasında pozitif yönde istatistiksel olarak anlamlı ilişki bulundu $(p<0,05)$

Sonuçlar: Tinnitus olgularının çocukluk çağı travmaları ile dissosiyatif yaşantıları arasında pozitif bir ilişki bulunmuştur ki bu durum tinnituslu hastalarda predispozan faktör olarak kabul edilebilir. Tinnituslu hastalar çocukluk çağı travması açısından araştırılmalı ve tedaviye multidisipliner yaklaşılmalıdır.

Anahtar kelimeler: Çocukluk çağı travmaları, dissosiyatif yaşantılar, depresyon, tinnitus

\section{INTRODUCTION}

Tinnitus is one of the most common symptoms of the hearing system and is described as the presence of sound in the ear or within the head without any external stimulation. Tinnitus originates from the Latin word "tinnire," and is classified as objective and subjective. The sound felt in objective tinnitus occurs as a result of muscle contractions in the head and neck region and turbulent blood flow ${ }^{1,2}$.

The most important feature of objective tinnitus is that the sounds that disturb the patient are also heard from outside. Sounds that cause objective tinnitus reflect the perception of internally produced sounds from joints, muscles, turbulent blood flow, or otoacoustic emission. The patient hears the real sound; however, it may not always be heard from outside and the physician may use devices, such as a stethoscope or microphone ${ }^{3}$. Contrarily, the more common condition of subjective tinnitus is an abnormal sound perception that is exclusively felt by the patient without any acoustic source, which is thought to occur as a result of abnormal neural activity that cannot be heard from the outside and occurs without sound stimulus. The pathology that causes subjective tinnitus can be anywhere from the external auditory canal to the auditory center ${ }^{4}$.

Otological causes, metabolic dysfunctions, neurological disorders, and pharmacological treatments can be involved in the etiology of subjective tinnitus ${ }^{1,2}$.

The generally accepted theory in the pathophysiology of tinnitus is the Jastreboff Neurophysiological Tinnitus Model $^{5}$, which is an approach that covers all hypotheses that are thought to play a role in the etiology and pathogenesis of tinnitus and provides a holistic explanation of the emergence and persistence of tinnitus. In this model, tinnitus is a nonspecific reflection of a disease that originates from the ear, auditory nerve, or central auditory center and is usually associated with hearing loss. Tinnitus is accepted to be caused by pathology in the auditory system or is caused by abnormal perception of normal neural activity even without sound in the auditory system ${ }^{6}$.

The underlying mechanism of tinnitus, in addition to the acoustic component, also includes cognitive, emotional, and memory components. These components are assumed to interact with each other. The emotional component determines the severity of tinnitus perceived by the patient. Research shows that the emotional effects of tinnitus and the discomfort experienced by patients are interrelated and originate from a common network in the brain $^{7.8}$.

Tinnitus might be an unaccompanied complaint or might be associated with symptoms, such as hearing loss and dizziness. This condition affects $15 \%$ of the general population, with a prevalence that reaches $33 \%$ in patients older than 60 years old 9 . Most tinnitus cases have no objective test to detect its presence or severity. Therefore, the diagnosis is based on the history that was taken from the patient and the evaluation of its effect on the patient ${ }^{10}$. The first thing to ask the patient is the first appearance, location, and characteristic of tinnitus. Particularly, a rhythmic or pulsatile component should be asked. The severity and frequency of tinnitus in patients can be measured to generate basic information, facilitate therapy, and investigate treatment effects. The following are the four stages of measuring tinnitus: tinnitus frequency, tinnitus severity, maskability, and residual inhibition".

Objective concepts, such as morbidity and mortality, are discussed in the evaluation of diseases. However, the patient is a combination of physical, mental, and social concepts and the recovery rates are higher in cases handled as a whole. Therefore, psychiatric symptoms have become one of the main study areas. Tinnitus can be accompanied by some psychiatric symptoms, such as somatization, anxiety, and depression. Levels of depression and anxiety are high in patients with tinnitus ${ }^{12}$. Many factors, such as physical and emotional, affect the 
ability to cope with tinnitus, and changes in tinnitus under stress affect the quality of life. The severity of patient complaints should be addressed, and it should be remembered that patients may attempt suicide under depression ${ }^{13}$.

Epidemiological studies on the frequency, severity, and duration of psychiatric symptoms in patients with tinnitus are very limited. Traumatic experiences in childhood affect the psychological functions in adulthood, and the psychological traumas experienced by the individual during childhood have been reported to be important contributors in dissociation formation ${ }^{14}$. Dissociative experiences originating from trauma causes division of personality structures that are closely related to the mental and behavioral characteristics of individuals. Dissociation, as an adaptation response to the usual dynamics of life and, prevents the loss of control of the lives of individuals to a certain extent. Despite physical control over time, dissociation turns into a permanent mechanism that creates a feeling of mental helplessness ${ }^{14}$.

Uncertainty in the etiopathogenesis of tinnitus continues today. The present study aimed to examine the relationship between childhood traumas, depressive symptoms, and dissociative experiences of cases with tinnitus. Thus, a possible relationship between variables will contribute to understand the disease etiology and regulate new dimensions in treatment approaches. The significance of the present study is its uniqueness within the relevant literature.

\section{MATERIALS and METHODS}

\section{Participants}

The study included 90 voluntary patients ( 45 patients with tinnitus and 45 in the control group) aged older than 18 years who applied to the otorhinolaryngology clinic between November 2018 and February 2019 and were diagnosed with subjective tinnitus. The study group was determined using the cluster sampling method. The control group consisted of completely healthy individuals. All patients that suffered from tinnitus for at least 3 months before the study with no visible improvement despite medication were subjected to ear, nose, and throat examination, and then their detailed medical history was collected. The characteristics of tinnitus were investigated to distinguish between subjective and objective tinnitus. Patients diagnosed with eardrums and/or middle ear pathology during the otoscopic examination were excluded from the study.
All patients were evaluated using pure tone audiometry and tympanometry. Further, temporal bone magnetic resonance imaging was performed in all patients to rule out retrocochlear pathology. Patients with diseases that may cause objective tinnitus, such as, otosclerosis, chronic otitis media, acoustic tumor, Meniere's disease, ear surgery history, and neuropsychiatric disease, were excluded from the study.

The study was approved by the local Scientific Research and Publication Ethics Committee (Inonu University Health Sciences Non-Invasive Clinical Research Ethics Committee) with decision number 2018/22-9 (date: 04.12.2018), and all patients were informed about the study before obtaining informed consent.

\section{Assessment}

Personal Information Form: A personal information form prepared by the authors was used to determine the sociodemographic characteristics of participants. Details, including the participants' gender, age, marital status, presence of chronic diseases, and psychiatric treatment history, were collected.

Dissociative Experiences Scale (DES): This self-report scale, developed by Bernstein and Putnam ${ }^{15}$ with 28 items, quantitatively rates dissociative experiences. Sar et al. ${ }^{16}$ tested and approved the Turkish validity and reliability of the scale. DES is not a diagnostic tool; rather, it is used for screening chronic dissociative disorders. The Turkish version of the scale has high validity and reliability, similar to the original scale. The possible score ranges between 0 and 100 , and the result is obtained by calculating the average of the total scores, wherein scores above 30 indicate the presence of dissociative disorder. The validity and reliability of studies conducted using this scale in Turkey showed high reliability of internal consistency (Cronbach's alpha $=0.91$ ) and test-retest correlation $(r=0.78)$. The internal consistency coefficient of the scale in the present study was 0.97 .

Childhood Trauma Scale (CTS): Şar et al..$^{17}$ performed the validity and reliability study of the Turkish version of the original CTS developed by Bernstein et al. $^{18}$. CTS is a self-report scale used for retrospectively and quantitatively evaluating the experiences of abuse and neglect before the age of 20 years. The scale comprises 28 items, wherein each item is scored between 1 and 5 . The scale contains five subdimensions, including sexual, physical, emotional, and emotional abuse, as well as physical neglect, and the total CTS score is calculated by summing the five subdimensions. All sub-scores range between 5 and 25 , whereas the total score ranges 
between 25 and 125. The Cronbach alpha value, which shows the internal consistency of the scale, was 0.93 for all participants ( $\mathrm{n}=123$ ), and the Guttman half-test coefficient was 0.97 . High scores on CTS indicate that the individual suffered from high levels of abuse and neglect. The internal consistency coefficient of the scale was 0.93 , and the test-retest reliability was 0.90 . The internal consistency coefficient of the scale was 0.72 .

Hospital Anxiety and Depression Scale (HADS): The HADS is frequently used to scan anxiety and depression symptoms in the form of a self-report scale in the hospital environment. HADS was developed by Zigmond and Snaith ${ }^{19}$, and its Turkish validity and reliability were verified by Aydemir et al. ${ }^{20}$. It contains 14 questions, 7 of which measure anxiety, and the other 7 measure depression. Aydemir et al. ${ }^{20}$ found that the cut-off scores for the anxiety and depression subscales (HADS-A and HADS-D) are 10 and 7, respectively. Thus, those who scored above these cut-off values are considered to be at risk.

\section{Statistical Analysis}

The statistical analysis of the data collected from patients through the patients' information form, CTS, and DES was performed using the Statistical Package for the Social Sciences 22.00 software. Descriptive statistics, such as frequency distribution, mean, independent t-test, and standard deviation were used to define the sample. The Pearson correlation analyses were used to determine the direction and level of the relationship among variables. The significance level was set at a $\mathrm{p}$-value of $<0.05$.

\section{RESULTS}

Sociodemographic characteristics, stratified by the tinnitus group and control group, are presented in Table 1. No statistically significant difference was found between the tinnitus group and the control group in terms of age, gender, education, marital status, employment status, and psychiatric illness ( $p>0.05)$.

\begin{tabular}{|c|c|c|c|}
\hline Variable & Tinnitus group & Control group & Statistical analysis \\
\hline \multicolumn{4}{|l|}{ Gender } \\
\hline Female, $\mathrm{n}(\%)$ & $20(44.40)$ & 23 (51.11) & $\chi^{2}=0.52 \quad p>0.05$ \\
\hline Male, $\mathrm{n}(\%)$ & $25(55.60)$ & $22(48.89)$ & \\
\hline \multicolumn{4}{|l|}{ Age } \\
\hline 20-30 years old, $\mathrm{n}(\%)$ & $13(28.90)$ & $14(31.11)$ & $\chi^{2}=0.38 \quad p>0.05$ \\
\hline 31-40 years old, n (\%) & $11(24.40)$ & $13(28.89)$ & \\
\hline $41-50$ years old, $\mathrm{n}(\%)$ & $11(24.40)$ & $9(20.00)$ & \\
\hline Over 51 years old, $\mathrm{n}(\%)$ & $10(22.20)$ & $9(20.00)$ & \\
\hline \multicolumn{4}{|l|}{ Marital status } \\
\hline Married, n (\%) & $32(71.10)$ & 35 (77.78) & $\chi^{2}=0.47 \quad p>0.05$ \\
\hline Single, $\mathrm{n}(\%)$ & $13(28.90)$ & $10(22.22)$ & \\
\hline \multicolumn{4}{|l|}{ Education status } \\
\hline Primary, n (\%) & $18(40.00)$ & 17 (37.78) & $\chi^{2}=1.14 \quad p>0.05$ \\
\hline High school, n (\%) & $16(35.60)$ & $16(35.56)$ & \\
\hline University, n (\%) & $11(24.40)$ & $12(26.67)$ & \\
\hline \multicolumn{4}{|l|}{ Working condition } \\
\hline Employed, n (\%) & $31(68.90)$ & $29(64.44)$ & $\chi^{2}=2.37 \quad p>0.05$ \\
\hline Unemployed, n (\%) & $14(31.10)$ & $16(35.56)$ & \\
\hline \multicolumn{4}{|l|}{ Psychiatric history } \\
\hline No, n (\%) & 35 (77.78) & $37(82.22)$ & $\chi^{2}=1.49 \quad \mathrm{p}>0.05$ \\
\hline Yes, n (\%) & $10(26.67)$ & $8(17.78)$ & \\
\hline \multicolumn{4}{|l|}{ Chronic disease } \\
\hline No, n (\%) & $34(75.56)$ & $36(80)$ & $\chi^{2}=2.83 \quad p>0.05$ \\
\hline Yes, n (\%) & $11(24.44)$ & $9(20)$ & \\
\hline
\end{tabular}


Table 2 shows the mean scores of the tinnitus group for CTS subdimensions, depression, and DESs. The CTS total score of the tinnitus group was $54.37 \pm 10.17$. The subdimensions of CTS included the emotional abuse score of $8.97 \pm 1.95$; physical abuse of $6.15 \pm 3.38$; sexual abuse of $5.57 \pm 1.58$; emotional neglect of $(14.97 \pm 3.93)$; physical neglect of $10.11 \pm 2.08$; and trauma underestimation of $8.57 \pm 2.35$. The CTS total score of the control group was $32.46 \pm 3.24$, wherein the subdimensions included the emotional abuse score of $5.82 \pm 1.82$; physical abuse of $4.11 \pm 1.21$; sexual abuse of $4.32 \pm 1.10$; emotional neglect of 10.81 \pm 2.25 ; physical neglect of $8.02 \pm 1.07$; and trauma underestimation of $5.12 \pm 2.41$. Accordingly, significant differences were found between the tinnitus and control groups in the total CTS score $(\mathrm{t}=1.21 ; \mathrm{p}<0.05)$.
The average HADS-D and HADS-A scores of the tinnitus group were $12.22 \pm 5.41$ and $10.54 \pm 3.57$, respectively, whereas in the control group, were $9.2 \pm 2.13$ and $8.12 \pm 1.98$, respectively. Accordingly, a statistically significant difference was found between the HADS-D and HADS-A score averages of the tinnitus and control groups $(t=0.45$; $\mathrm{p}<0.05)$.

The total DES score of the tinnitus $(13.48 \pm 4.68)$ and control groups $(8.27 \pm 3.42)$ was determined. Accordingly, a statistically significant difference was found between the DES score averages of the tinnitus and control groups $(t=0.45 ; \mathrm{p}<0.05)$.

Table 3 presents a positive correlation $(p<0.05)$ between the total scores of CTS of patients and the subdimensions of emotional abuse, physical abuse,

\begin{tabular}{|c|c|c|c|c|}
\hline Scales & Case group & Control group & & \\
\hline Childhood trauma subdimensions & $\overline{\mathbf{X}}$ SD & $\overline{\mathbf{X}} \mathbf{S D}$ & $\mathbf{t}$ & $\mathbf{P}$ \\
\hline Emotional abuse & $8.97(1.95)$ & $5.82(1.82)$ & & \\
\hline Physical abuse & $6.15(3.38)$ & $4.11(1.21)$ & & \\
\hline Sexual abuse & $5.57(1.58)$ & $4.32(1.10)$ & & \\
\hline Emotional neglect & $14.97(3.93)$ & $10.81(2.25)$ & & \\
\hline Physical neglect & $10.11(2.08)$ & $8.02(1.07)$ & & \\
\hline Trauma underestimation & $8.57(2.35)$ & $5.12(2.41)$ & & \\
\hline Total childhood trauma & $54.37(10.17)$ & $32.46(3.24)$ & 1.21 & 0.03 \\
\hline Dissociative Experience Scale & $13.48(4.68)$ & $8.27(3.42)$ & 0.45 & 0.02 \\
\hline Hospital Anxiety and Depression Scale-Depression & $12.22(5.82)$ & $9.2(2.13)$ & 0.92 & 0.04 \\
\hline Hospital Anxiety and Depression Scale-Anxiety & $10.54(3.57)$ & $8.12(1.98)$ & 1.83 & 0.02 \\
\hline
\end{tabular}

\begin{tabular}{|c|c|c|c|c|c|c|c|c|c|}
\hline Scale/subdimensions & 1 & 2 & 3 & 4 & 5 & 6 & 7 & 8 & 9 \\
\hline 1. CTQ total & 1 & & & & & & & & \\
\hline 2. Emotional abuse & $0.427^{*}$ & 1 & & & & & & & \\
\hline 3. Physical abuse & $0.420^{*}$ & 0.825 & 1 & & & & & & \\
\hline 4. Sexual abuse & $0.429^{*}$ & 0.852 & 0.410 & 1 & & & & & \\
\hline 5. Emotional neglect & $0.348^{*}$ & 0.889 & 0.370 & 0.174 & 1 & & & & \\
\hline 6. Physical neglect & $0.410^{*}$ & 0.784 & $0.582^{*}$ & 0.458 & 0.859 & 1 & & & \\
\hline 7. HADS-D & $0.542^{*}$ & 0.824 & 0.321 & 0.753 & $0.874^{*}$ & 0.548 & 1 & & \\
\hline 8. HADS-A & $0.318^{*}$ & 0.819 & 0.810 & 0.734 & 0.777 & $0.425^{*}$ & 0.485 & 1 & \\
\hline 9. DES total & $0.420^{*}$ & 0.528 & 0.725 & 0.236 & 0.258 & 0.158 & $0.358^{*}$ & 0.748 & 1 \\
\hline
\end{tabular}


physical neglect, sexual abuse, emotional neglect, depression, and dissociative experiences [Total, $(r=0.420$, $\mathrm{p}<0.05)$; emotional abuse, $(\mathrm{r}=0.271, \mathrm{p}<0.05)$; physical abuse, $(r=0.214, p<0.05)$; sexual abuse, $(r=0.429, p<0.05)$; emotional neglect, $(r=0.348, p<0.05)$; physical neglect, $(r=0.410, p<0.05)]$.

\section{DISCUSSION}

This study investigated the relationship between neglect and abuse experiences and depressive symptoms and dissociative experiences in the childhood years of cases and tinnitus. No statistically significant difference was found in the sociodemographic data of the groups. The examination of gender distribution revealed that $44.40 \%$ of patients were females and $55.60 \%$ were males. The examination of tinnitus incidence in adult patients in society revealed that the incidence of tinnitus is higher in males in some studies in terms of gender distribution ${ }^{21}$, of which our study results coincide.

A statistically significant difference was found between childhood trauma, depressive symptoms, and dissociative experiences of the tinnitus and control groups. Tinnitus cases were observed to be affected by childhood traumas. The severity of childhood traumas was very low in the control group consisting of healthy individuals. Moreover, significant differences were found when other variables were compared (i.e., depressive and dissociative symptoms) ${ }^{22}$. Individuals with tinnitus were determined to have higher mean scores for depressive symptoms than healthy individuals. A large-scale study conducted in America included approximately 21.4 million, wherein those with tinnitus (anxiety in $26.1 \%$ and depressive symptoms in $25.6 \%$ ) were higher than those without (anxiety in $9.2 \%$ and depressive symptoms in $9.1 \%)^{23,24}$.

Our study results revealed that patients with tinnitus are affected by childhood trauma, depressive symptoms, and dissociative experiences. Another important finding of this study is the statistically significant positive correlation between the total score of CTS and HAD ( $r=0.542, p<0.05$ and $\mathrm{r}=0.874, \mathrm{p}<0.05)$. The positive significant correlation found in the present study between childhood trauma and depressive symptoms is supported by other studies, which claim that childhood traumatic experiences may be a risk factor for psychiatric disorders in the future. A person may experience depression, anxiety, and hostility due to traumatic experiences in their childhood, which may leave lifelong effects. In recent years, the number of studies investigating the effects of childhood trauma on the occurrence of most psychiatric disorders have been rapidly increasing and the relationships between childhood trauma and different psychiatric disorders (somatic symptom disorders, sleep disorders, personality disorders, obsessive-compulsive disorder, anxiety, and depression) have been addressed in the literature ${ }^{25-27}$. In the context of relevant literature, a significant relationship was found between university students' obsessivecompulsive symptoms, childhood traumatic experiences, and dissociation scores ${ }^{28}$. A study on gender-specific differences in childhood traumas and coping attitudes of major depression revealed that depression severity is an independent predictor for using emotionally focused and dysfunctional coping methods in males ${ }^{29}$. The study on the relationship between depression, anxiety, and dissociation symptoms based on childhood traumas revealed a positive relationship between depressionanxiety symptoms in all types of neglect and abuse except physical abuse. Moreover, a positive relationship was observed between anxiety-dissociation symptoms in all types of neglect and abuse, except for sexual abuse ${ }^{30}$. Another study showed that childhood traumas negatively affect patients with major depressive and bipolar disorders ${ }^{31}$. Further, a study on the relationship between childhood trauma and aggression levels in adults revealed that childhood trauma predisposes to adult aggression ${ }^{32}$. A study on the role of childhood traumas in psychiatric features in patients with neurotic excoriation revealed that childhood traumas were likely to have an important role in the formation of both neurotic excoriation and accompanying psychiatric problems ${ }^{33}$.

The important finding of the study is the statistically positive significant relationship between the CTS and DES scores of cases with tinnitus $(r=0.420 ; p<0.05)$. Moreover, a significant positive relationship was found between emotional abuse and dissociative experiences sub-dimension of CTS ( $r=0.381 ; \mathrm{p}<0.05)$. According to this result, as the childhood emotional abuse score of the cases with tinnitus increases, the dissociative experience score also increases. The literature presented studies that indicate a relationship between childhood trauma and dissociative symptoms. Previously, families of sick individuals were reported to experience significant levels of childhood traumas ${ }^{34-36}$. Especially, stress and emotional trauma in early childhood are observed to increase the symptoms of tinnitus in adulthood.

The present study shows that a positive correlation exists between tinnitus and depressive symptoms. Depression level increases with the severity of tinnitus. 
A difference was found between the mean scores of the tinnitus cases and the control group. Wilson et al. ${ }^{37}$ found that patients with tinnitus may have symptoms, such as unhappiness, tension, irritability, indifference to the environment, sleep disorders, inability to enjoy life, loss of concentration, loss of working skills, and avoidance of social environment. Moreover, studies reported that the perception of tinnitus increases due to psychological reasons and symptoms, such as anxiety, sleep disorders, and depression, which are more common in tinnitus cases, and perception of tinnitus may increase due to increased environmental stress ${ }^{38,39}$. Prior studies that examined the relationship between tinnitus and depression revealed that tinnitus affects several aspects of an individual's life ${ }^{40,41}$. In addition, emotional states with depression symptoms are observed in patients with tinnitus complaints. A study revealed that the level of tinnitus affects depression and the level of depression affects tinnitus ${ }^{42-44}$. In correlation analysis, strong relationships between childhood neglect and abuse experiences, depressive symptoms, and dissociative experiences were observed. Emotional and physical violence exposure during childhood negatively affects tinnitus cases.

The insufficient measurement with the visual analog scale questionnaire in this study can be cited as one of the limitations. Further, the CTS, HADS, and DES can be subjectively interpreted by patients while filling out the scales. Concurrently, the CTS includes questions about the past and patients are likely to forget or deny their traumatic experiences.

\section{CONCLUSION}

The study results found a positive relationship between the childhood traumas and dissociative experiences of tinnitus cases. Depressive symptoms and dissociative experiences increase as childhood traumas increase. Studies with larger samples must be performed to reveal the relationship between tinnitus and childhood trauma, dissociative experiences, and depression in a more comprehensive way.

Our study revealed that most patients with tinnitus show depressive symptoms. The average total score for childhood trauma was high in the present study. Therefore, diagnosis and treatment of neuropsychiatric and psychological symptoms are recommended to provide appropriate treatment methods in tinnitus cases. Childhood trauma should be investigated in patients with tinnitus, and treatment should be approached in a multidisciplinary manner. An intense need for methods that clearly show the severity of tinnitus was found; however, no consensus was found on the methods used to determine the severity of tinnitus. The severity of tinnitus can be determined by learning its occurrence, how much it disturbs the patient, and how much it limits daily activities. The only way to achieve this is through surveys. Tinnitus is a multifactorial disease, thus using more than one questionnaire to determine the different complaints that occur in each patient is necessary.

\section{Ethics}

Ethics Committee Approval: The study was approved by the local Scientific Research and Publication Ethics Committee (Inonu University Health Sciences NonInvasive Clinical Research Ethics Committee) with decision number 2018/22-9 (date: 04.12.2018).

Informed Consent: All patients were informed about the study before obtaining informed consent.

Peer-review: Externally and internally peer-reviewed.

\section{Author Contributions}

Concept: M.A., D.S., E.O., O.C., Design: M.A., D.S., E.O., O.C., Data Collection and/or Processing: M.A., D.S., E.O., O.C., Analysis and/or Interpretation: M.A., D.S., E.O., O.C., Critical revision: M.A., D.S., E.O., O.C., Writing: M.A., D.S., E.O., O.C.

Conflict of Interest: The authors declare that they have no conflict of interest.

Financial Disclosure: The authors declared that this study has received no financial support.

\section{REFERENCES}

1. Dobie RA. Overview: suffering from tinnitus. In: Snow JB, editor. Tinnitus: Theory and Management. Ontario: BC Decker Inc; 2004. p. 1-7.

2. Grossan M, Peterson DC. Tinnitus. StatPearls. Treasure Island (FL): StatPearls Publishing Copyright $\odot$ 2020, StatPearls Publishing LLC.; 2020.

3. Akyıldız N. Tinnitus, Ear diseases and microsurgery II. Scientific Medicine Publisher. 2002.

4. Roberts LE, Eggermont JJ, Caspary DM, Shore SE, Melcher JR, Kaltenbach JA. Ringing ears: the neuroscience of tinnitus. J Neurosci. 2010;30:14972-9.

5. Jastreboff P, Hazell J. Tinnitus Retraining Therapy: Implementing the Neurophysiological Model. Cambridge: Campbridge University Press; 2008.

6. Jastreboff PJ, Jastreboff MM. Tinnitus retraining therapy: a different view on tinnitus. J Otorhinolaryngol Relat Spec. 2006;68:23-30.

7. James AH, Larry ER, Donald MC, Sarah MT, Richard JS. Underlying Mechanisms of Tinnitus: Review and Clinical Implications. J Am Acad Audiol. 2014;25:5-126. 
8. Baldo P, Doree C, Molin P, McFerran D, Cecco S. Antidepressants for patients with tinnitus. Cochrane Database Syst Rev. 2012;2012:CD003853. doi: 10.1002/14651858.CD003853.pub3.

9. Kim H-J, Lee H-J, An S-Y, et al. Analysis of the prevalence and associated risk factors of tinnitus in adults. PLoS One. 2015;10:e0127578. doi: 10.1371/journal.pone.0127578.

10. Simôes JP, Neff PKA, Langguth B, et al. The progression of chronic tinnitus over the years. Sci Rep. 2021;11:4162.

11. Derin S, Beydilli H, Acar E, Sahan M, Sahan L. Tinnitus-Induced Suicide. Meandros Med. Dent. 2015;16:30-1.

12. Hinton DE, Chhean D, Pich V, Hofmann SG, Barlow DH. Tinnitus among Cambodian refugees: relationship to PTSD severity. J Trauma Stress. 2006:19:541-6.

13. Langguth B, Landgrebe M, Kleinjung T, Sand GP, Hajak G. Tinnitus and depression. World J Biol Psychiatry. 2011:12:489-500.

14. Robinson SK, McQuaid JR, Viirre ES, et al. Relationship of tinnitus questionnaires to depressive symptoms, quality of well-being, and internal focus. Int Tinnitus J. 2003;9:97-103.

15. Bernstein EM, Putnam FW. Development, reliability, and validity of a dissociation scale. J Nerv Ment Dis. 1986;174:727-35.

16. Sar V, EK, TK, Bakim B, Yargic I, HT. Validity and Reliability of the Turkish Version of the Dissociative Experiences Scale (DES-II). Annual Turkish Psychiatry Conference; Ankara 1997.p. 55-63.

17. Şar V, Öztürk E, İkikardeş E. Validity and reliability of the Turkish version of the Childhood Psychiatric Trauma Scale. Turkiye Klinikleri J Med Sci. 2012;32:1054-63.

18. Bernstein DP, Fink L, Handelsman L, Foote J. Childhood trauma questionnaire. Assessment of family violence: A handbook for researchers and practitioners. Washington: American Psychological Association; 1998.

19. Zigmond AS, Snaith RP. The hospital anxiety and depression scale. Acta Psychiatr Scand. 1983;67:361-70.

20. Aydemir Ö, Guvenir T, Kuey L, Kultur S. Validity and reliability of Turkish version of hospital anxiety and depression scale. Turk J Psychiatry. 1997;8:280-7.

21. Bhatt JM, Bhattacharyya N, Lin HW. Relationships between tinnitus and the prevalence of anxiety and depression. Laryngoscope. 2017;127:466-9.

22. Choi J, Lee CH, Kim SY. Association of tinnitus with depression in a normal hearing population. Medicina (Kaunas). 2021;57:114.

23. Temugan E, Yildirım RB, Onat $\mathrm{H}$, et al. Does tinnitus lead to depression? Clin Investig Med. 2016;39:27505.

24. Pattyn T, Van Den Eede F, Vanneste S, et al. Tinnitus and anxiety disorders: a review. Hear Res. 2016;333:255-65.

25. Demirci K. The Investigation of relationship between childhood trauma and obsessive compulsive symptoms. J Mood Disord. 2016;6:1.

26. Helvaci Celik F, Hocaoglu C. Childhood traumas: a review. Sakarya Med J. 2018;8:695-711.

27. Gül A, Gül H, Erberk Özen N, Battal S. Differences between childhood traumatic experiences and coping styles for male and female patients with major depression. Turk J Psychiatry. 2017;28:246-54.
28. Gul A, Gul H, Ozen N, Battal S. An Investigation study about the relationship of depression, anxiety and dissociation symptoms on the background of childhood traumas. J Mood Disord. 2016;6:1.

29. Perna G, Vanni G, Di Chiaro NV, Cavedini P, Caldirola D. Childhood trauma, temperament, and character in subjects with major depressive disorder and bipolar disorder. J Nerv Ment Dis. 2014;202:695-8.

30. Simsek DE, Evrensel A. The relationship between childhood traumas and aggression levels in adults. Med Sci. 2018;7:622-6.

31. Yalçin M, Tellioğlu E, Yildirim DU, Savrun BM, Özmen M, Aydemir EH. Psychiatric features in neurotic excoriation patients: the role of childhood trauma. Noro Psikiyatr Ars. 2015;52:336-41.

32. Orsel S, Karadag H, Karaoğlan Kahiloğullari A, Aktaş E. The frequency of childhood trauma and relationship with psychopathology in psychiatric patients. Anatol J Psychiatry. 2011;12:130-6.

33. Ozturk E. Spiritual Trauma and Dissociation. Turaz Academy, Forensic Sciences. İstanbul: Academician Bookstore; 2018. p. 92-106.

34. Ozturk E. Trauma and Dissociation Psychotraumatology Basic Book (Trauma Based Alliance Model Therapy: Psychotherapy of Dissociative Identity Disorder). 2nd ed. Istanbul: Nobel Publishing House; 2020.

35. Sar V, Taycan O, Bolat N, et al. Childhood trauma and dissociation in schizophrenia. Psychopathology. 2010;43:33-40.

36. Baran H, Gokdogan O, Cakabay T. Comparison of tinnitus handicap inventory with beck depression and anxiety inventories. ENT Applications. 2016;4:7-11.

37. Wilson PH, Henry J, Bowen M, Haralambous G. Tinnitus reaction questionnaire: psychometric properties of a measure of distress associated with tinnitus. J Speech Hear Res. 1991;34:197-201.

38. Dobie RA. Tinnitus and depression. Int Tinnitus J. 1997;3:33-4.

39. Ziai K, Moshtaghi O, Mahboubi H, Djalilian HR. Tinnitus patients suffering from anxiety and depression: a review. Int Tinnitus J. 2017;21:68-73.

40. Reyome ND. Childhood emotional maltreatment and later intimate relationships: themes from the empirical literature. J Aggress Maltreatment Trauma. 2010;19:224-42.

41. Thompson DM, Hall DA, Walker DM, Hoare DJ. Psychological therapy for people with tinnitus: a scoping review of treatment components. Ear Hear. 2017;38:149-58.

42. Ozturk E. Trauma based alliance model therapy. Med Sci 2021;10:63150.

43. Kivrak Y, Gey N, Kivrak HA, Kokacya MH, Copoglu ÜS, Ari M. Spousal violence against women, childhood traumas, depression and quality of life: Community based work. Anatol J Psychiatry. 2016;16:314-22.

44. Bartels H, Pedersen SS, van der Laan BF, Staal MJ, Albers FW, Middel B. The impact of Type D personality on health-related quality of life in tinnitus patients is mainly mediated by anxiety and depression. Otol Neurotol. 2010;31:11-8. 